\title{
First report of winter survival of Phakopsora pachyrhizi on kudzu (Pueraria lobata), in the province of Buenos Aires, Argentina
}

\author{
Miguel Lavilla ${ }^{1} \cdot$ Antonio Ivancovich $^{1}$
}

Published online: 12 March 2019

(C) The Author(s) 2019

Keywords Soybean rust · Fungus survival · Molecular characterization of Phakopsora pachyrhizi

Asian soybean rust (ASR), caused by Phakopsora pachyrhizi, was first reported in 2002 in Argentina (Rossi 2003). This pathogen was found not only on soybean but also on several alternative hosts like cajan (Cajanus cajan), kudzu (Pueraria lobata) and mucuna (Mucuna cochinchinesis). A molecular differentiation was carried out using the polymerase chain reaction (PCR) assay described by Frederick et al. (2002). The occurrence of ASR in the main soybean area of the provinces of Buenos Aires, Córdoba, Santa Fe and Entre Ríos depends on the arrival of urediniospores coming from northern region of Argentina and from Brazil, Paraguay and Uruguay. Weather conditions in Argentina generally do not support the survival of ASR on soybean nor on alternative hosts, as these hosts usually do not survive the winter. Winter conditions in La Plata, during 2017, were milder than normal. Kudzu is the main alternative host of ASR in Argentina and has been found in Cerro Azul (province of Misiones), Pergamino and La Plata (province of Buenos Aires), where ASR on kudzu is commonly observed. ASR had never survived on kudzu in the province of Buenos Aires, however in September 2017 (i.e. after the winter) ASR was found on kudzu in La Plata, surviving the winter. Identification of Phakopsora pachyrhizi on kud$\mathrm{zu}$ was made based on morphological characters and on our experience with this fungus during 15 years. The implication of this event must be studied in order to determine its possible effect on the cycle of ASR in Argentina.

Open Access This article is distributed under the terms of the Creative Commons Attribution 4.0 International License (http:// creativecommons.org/licenses/by/4.0/), which permits unrestricted use, distribution, and reproduction in any medium, provided you give appropriate credit to the original author(s) and the source, provide a link to the Creative Commons license, and indicate if changes were made.

Publisher's note Springer Nature remains neutral with regard to jurisdictional claims in published maps and institutional affiliations.

\section{References}

Frederick RD, Snyder CL, Peterson GL, Bonde MR (2002) Polymerase chain reaction assays for the detection and discrimination of the soybean rust pathogens Phakopsora pachyrhizi and P. meibomiae. Phytopathology 92(2):217-227

Rossi RL (2003) First report of Phakopsora pachyrhizi, the causal organism of soybean rust in the province of Misiones, Argentina. Plant Dis $87: 102$

Miguel Lavilla

miguellavillapergamino@gmail.com

$\triangle$ Antonio Ivancovich

ajivancovich@comunidad.unnoba.edu.ar

1 UNNOBA (University of Northern Province of Buenos Aires), Monteagudo 2772, C.P.2700 Pergamino, province of Buenos Aires, Argentina 